\title{
PERFORMANCE MEASUREMENT SYSTEMS IN THE CONTEXT OF NEW PUBLIC MANAGEMENT: EVIDENCE FROM AUSTRALIAN PUBLIC SECTOR AND POLICY IMPLICATIONS FOR DEVELOPING COUNTRIES
}

\author{
Anup Chowdhury, Nikhil Chandra Shil \\ East West University, Bangladesh \\ E-mail: anup@ewubd.edu, nikhil@ewubd.edu
}

\begin{abstract}
This research explored in depth the evolution of performance measurement systems in the context of new public management initiatives in Australian public sector. A governmental department in the Australian Capital Territory was selected for the purpose of the exploration. The qualitative research approach was adopted and data was collected following case study tradition. The main data sources were archival official documents and interviews. In addition, the researchers used direct observation to supplement and corroborate the archival documents and interview data. The empirical evidence presented in this research supports the fact that the selected Australian government department has implemented performance measurement systems in the line of new public management to illustrate the department's commitment to efficiency and accountability. The research undertaken was in-depth, using a case study and though generalization is not possible from this single case study, the findings may be expected to add knowledge to existing literature and provide some important lessons for other public sector entities of the developing countries who are interested in adopting performance measurement systems as their control devices.

Keywords: public sector, performance measurement systems, new public management, developing countries, Australia.
\end{abstract}

\section{Introduction}

The term 'New Public Management' (NPM) is used to describe the changing style of governance and administration in the public sector. The most definitive characteristic of the NPM is the greater salience that is given to what has been referred to as the three 'Es'-economy, efficiency and effectiveness (Barrett, 2004). NPM is the commonly used label for the ambition of government organizations in many countries to run the public sector in a more businesslike manner (Jansen, 2004). During the 1980s and 1990s the term NPM was used to denote a number of reforms that were carried out by several countries in the world (Sahlin-Anderson, 2001). Maor (1999) also observed that NPM has shown a remarkable degree of consensus among the opinion makers of various countries about the desired nature of changes in the public sector.

In the line of the NPM the drive for reform in the public sector worldwide has focused attention on the measurement of performance in public sector organizations (Kloot \& Martin, 2000; Brignall \& Modell, 2000). Hughes (1995) argued that performance and its measurement is vital for the new public management to work. Osborne and Gaebler (1992) mentioned: 
Anup CHOWDHURY, Nikhil Chandra SHIL. Performance measurement systems in the context of new public management: Evidence from Australian public sector and policy implications for developing countries

PROBLEMS

OF MANAGEMENT

IN THE $21^{\text {st }}$ CENTURY

Vol. 12, No. 1, 2017

If you do not measure results, you cannot tell success from failure. If you cannot see success, you cannot reward it. If you cannot reward success, you are probably rewarding failure. If you cannot see success, you cannot learn from it. If you cannot recognize failure, you cannot correct it. If you can demonstrate results, you can win public support.

Performance measurement in the public sector worldwide was developed since the late 1970s. The terms were performance measures, performance indicators, performance appraisal and review, value for money and more recently quality assurance (Boland \& Fowler, 2000). This new notion has developed within the public sector which is concerned with collecting, reporting and appraising organisational performance. Brignall and Modell (2000) pointed out that during the 1980s in what has become known as the 'new public sector' has come under pressure to become more efficient and effective. To achieve the efficiency and effectiveness, public sector organizations introduced various private sector management control techniques such as performance measurement systems. However, it can also be argued that performance measurement is inherently more difficult in the public sector. At the same time it is crucial to gain public confidence that tax revenues are being used effectively (Ross, 2012). This paper concludes from the case study that the Australian public sector is in the process of various reforms initiative and it has implemented some private sector performance measures successfully with a motive to improve performances in provision of services to public.

\section{Background to the Problem}

During the 1990s the public sector adopted various private sector techniques and implemented multidimensional performance measurement and management systems (Brignall \& Modell, 2000; McAdam et al., 2005; Diefenbach, 2009). The changes of the managerial program in the Australian public sector have shifted to an emphasis on outputs and outcomes rather than inputs and processes (Tanner, 2008). A focus on outputs means that performance and its measures are crucial. Heinrich (2002) suggested that public managers can use the outcome based performance management framework to improve organisational performance. Hughes (1995) claimed that as a direct result of setting strategy and objectives, dividing activities in a programmatic way and funding them accordingly, measuring performance at all levels is essential in this regard. Hoque (2008) argued that in Australia, performance measurement systems are central to the government department's strategic planning and management framework. Hoque (2008) further argued that there is a clear linkage between the introduced 'managing for outcomes' framework and performance measurement practices of government departments. Buckmaster (1999) also argued that outcome measurement procedures have been advocated as a means of eliciting better accountability and more effective program evaluation by non-profit organisations. Buckmaster (1999) further argued that outcome measurement can be used effectively as a tool for learning, and formulation of new strategies thereby providing feedback to program managers in non-profit organisations.

Since the early 1980 s the Australian public sector has undergone major changes in its philosophy, structure, processes, and orientation and the main objectives of these changes were to establish formal rational management, necessity for clear goal, corporate plans, internal and external accounting systems with clear responsibility lines for output performance measurement (Parker \& Guthrie, 1993). Coventry and Nutley (2001) illustrated the change management in the Australian public sector. They mentioned that change had become a permanent feature of the public sector landscape in Australia. They argued that prior to 1980s change in the Australian public sector was mainly incremental expansion. After this period radical changes have occurred which affected financial management, budgetary reforms, structural change, senior executive appointments, commercialization, corporatization and some privatization of government programs. Halligan (2009) commented that Australian government had concentrated on management reform during the 1980s, but increasingly accepted the need 
for market-oriented reform. Halligan (2009) further argued that major changes to financial management were changing the method of budgeting and resource management which was based on the framework of outcomes and outputs and accrual accounting principles. In recent years an agenda to promote good governance and improved transparency of the Australian public sector budgetary and financial management is the Operation Sunlight (Tanner, 2008). It derives from a critical evaluation of the existing outcomes and outputs frameworks. The key objectives of Operation Sunlight are: tightening the outcomes and outputs framework, changing the Budget Papers to improve their readability and usefulness, improving the transparency of estimates and expanding the reach of Budget reporting, improving intergenerational reporting (Murray, 2008).

Evans and Bellamy (1995) pointed out that there were various changes and different types of programs implemented at all levels in the Australian public sector. They mentioned that these changes were implemented through the introduction of private sector-style management control systems (MCS) which included planning, coordinating, communicating, evaluating, acting and influencing. The present research is about the exploration of performance measurement systems in the context of NPM initiatives. The NPM initiatives created the changes to the structure and processes of public sector organizations with the objective of getting them to run better. A government department in Australia has been adopted as a field of investigation for the purpose of this exploration. Against this background, this research will investigate how the performance measurement systems have been implicated in the organizational environment within this selected government department. The research will seek the answers of the following research questions:

General aim: How have private sector performance measurement systems become embedded in the financially and managerially oriented selected public sector organization?

Specific Objectives: More particularly, the research seeks answer to the following questions:

a) How has the researched organization adopted private sector oriented performance measurement systems within their organization?

b) In what ways are performance measurement systems linked to the organizational actions of the researched organization?

c) How have performance measurement systems contributed to and shaped new organizational culture within the researched organization?

\section{Theoretical Framework of the Research}

Over the last two decades it was observed that a series of alternative approaches has been used in qualitative research. One of these approaches is motivated by interpretive sociology (Glaser \& Strauss, 1968; Schutz, 1967). Interpretive perspective epistemologically believes that social meaning is created during interaction and people's interpretations of interactions (HesseBiber \& Leavy, 2006; Cresswell, 2007; Gaffikin, 2008). Chua (1988) argued that interpretive sociology refers to an intellectual tradition, which focuses on the constructive and interpretive action of people. Llewelyn (2003) observed that qualitative research using interpretive methodologies now has become increasingly influential. According to these methodologies, performance measurement systems are not natural phenomena, they are socially constructed and they can be changed by social actors (Ryan et al., 1992). In order to gain a better understanding about the performance measurement systems in an organization, it is necessary to look at the relationship between day-to-day social action and the various dimensions of social structure. The present research has adopted an interpretive approach and used Giddens's structuration theory to understand how performance measurement systems, one of the important management control systems of an organization, are implicated in their social setting. The epistemological and ontological belief also inspired the researchers to adopt Giddens' structuration theory in 
Anup CHOWDHURY, Nikhil Chandra SHIL. Performance measurement systems in the context of new public management: Evidence from Australian public sector and policy implications for developing countries

PROBLEMS

OF MANAGEMENT

IN THE $21^{\text {st }}$ CENTURY Vol. 12, No. 1, 2017

10 this research. Here, it is assumed that multiple realities can exist in a given situation and for this reason the intention of the research is to promote a subjective research. The following Figure shows Giddens's structuration framework.

\begin{tabular}{|c|c|c|c|c|c|}
\hline structure & signification & $\ldots$ & domination & $\ldots$ & legitimation \\
\hline modality & interpretive scheme & $\ldots$ & facility & $\ldots$ & norm \\
\hline interaction & communication & $\ldots$ & power & $\ldots$ & sanction \\
\hline
\end{tabular}

Figure 1: Structuration framework.

(Source: Giddens, 1984, p. 29)

The third line of the above figure refers to the elements of interaction: communication, power and sanction. Second line represents modalities which refer to the mediation of interaction and structure in processes of social reproduction (Giddens, 1984, p. 29). Here modalities are interpretive scheme, facility and norm. Those on the first line are characterizations of structure, signification, domination and legitimation. Signification refers to the communication of meaning in interaction. It is the cognitive dimension of social life which has interpretative schemes. Interpretive schemes are 'standardized elements of stock of knowledge, applied by actors in the production of interaction' (Giddens, 1984, p.30). In the signification structure, agents draw upon interpretative schemes in order to communicate with each other and at the same time reproduce them. In the domination structure the use of power in interaction involves the application of facilities. The facilities are both drawn from an order of domination and at the same time, as they are applied, reproduce that order of domination (Giddens, 1984, p.30). The final structure is that of legitimation which involves moral constitution of interaction, and the relevant modality here is the norms of a society or community which draw from a legitimate order, and yet by that very constitution reconstitute it (Giddens, 1976, p. 123). These three structures constitute the shared set of values and ideals about what is important and should happen in social settings. Giddens $(1976,1979$, and 1984) identified that actors are not simply as social dupes governed by independent structures, but rather as existential beings who reflexively monitor their conduct and make choices in social settings.

\section{Methodology of Research}

This research is designed to explore the evolution of performance measurement systems in the context of NPM initiatives in Australia. A governmental department in the Australian Capital Territory (ACT) was selected as a case for the purpose of the exploration. This department was formed in 2002 to assist people with disability, and to cater to needs in housing and community services. The department performs a variety of functions and its responsibilities include people with a disability, social housing, children and young people, families, therapy services, careers, women, ageing, multicultural affairs, community services and facilities, Aboriginal and Torres Strait Islander people, homelessness and concession. In fact, The ACT Government has made things easier by bringing most of its human services into a one-stop department. The ACT Government has given this department wide responsibility to provide, or fund, human services for the Canberra community. In addition to these responsibilities, they have an obligation to implement formal agreements with other Australian governments and comply with laws passed by the ACT Legislative Assembly. The selected researched department works in partnership with community, private sector and government agencies in the delivery of the human services. It has already been mentioned that the Australian public sector has implemented a wide range of financial and administrative reforms. These reforms were linked to the NPM. The NPM 
techniques are the expression of developing new ideas, ideologies which reinvented the public sector management. The selected researched government department has adopted many of these managerial practices from the private sector. To meet the demand of the NPM reforms the researched department has implemented performance measurement systems a managerialist philosophy borrowed from private sector. In this research, to explore the systems, performance measurement indicators are classified into two groups: financial and non-financial. Financial indicators are: output based on budgeting, accounting and reporting systems, comparison of actual results with the budgeted amounts, monitoring output classification. Non-financial indicators are strategic indicators, number of client accessing service, independent external client satisfaction survey.

The qualitative research approach was adopted and data was collected in the case study tradition. By using qualitative research methodology, this research is something like naturalistic inquiry (Guba \& Lincoln, 1981) which has provided a thick description (Geertz, 1973). The main data sources were archival official documents and interviews. In this research, documentary evidence provided an important data source. Approximately 5,000 pages of official organizational documents were collected during the research which included the annual reports from the establishment of the department to date, meeting minutes, budget papers, strategic plan of the department, Restrictive Practices Framework, Ministerial and Assembly Guidelines and Procedures, Collective Agreement, Compliance Governance Framework etc. These official documents helped the research to supplement and corroborate the interview data.

The epistemological position influenced the researchers to conduct interviews because it allows a legitimate or meaningful way to generate data by talking interactively with people, to ask them questions, to listen to them, to gain access to their accounts and articulations, or to analyze their use of language and construction of discourse (Mason, 2002). The primary interview method used in this research was unstructured and open-ended. In this research, twenty top, mid and junior level staffs were interviewed. Snowball sampling technique was used. The interview proceedings were tape recorded with the consent of the participant. For safety reasons, back-up notes were also taken and checked and compared when the transcriptions were made. The interview tapes were transcribed later word for word. Key interview transcripts were fed back to the respective interviewees to establish the validity of the interview data. At the very beginning of each of the interview sessions the researcher discussed the background issues with the participant in an informal way according to the respondents' characteristics (say for example, job position). Before conducting the interviews one of the researchers listed the discussion issues. However, during the interview sessions, they were not followed up in a fixed order. The duration of these interviews were about an hour on average.

Direct observation was also used in this research to supplement and corroborate the archival documents and interview data. In this research, observation data came from casual watching and attending a number of informal meetings and information sessions within the department. The researchers attended five morning tea sessions, where they observed that the staffs were involved in discussing and debating on the organizational matters. It helped the researchers to gain first-hand information about the organization. It also allowed the researcher to observe the issues that participants may not be willing to disclose in the formal interviews (Patton, 2002). In the observation stage, data were collected in the field notes. All field notes were dated with appropriate reference number, time, place, attendees and researcher's opinion towards the situation. The departmental staffs with whom the researcher came into contact were very co-operative and seemed really interested in this research. In qualitative inquiry, data collection is not an end. It requires analysis, interpretation and presentation of findings (Patton, 2002; Irvine \& Gaffikin, 2008; Merriam, 2009; Nagy et al. 2010). In this research, the researchers analyzed data using the approach provided by Miles and Huberman (1994) which includes data reduction, data display and conclusion drawing and verification. 
Anup CHOWDHURY, Nikhil Chandra SHIL. Performance measurement systems in the context of new public management: Evidence from Australian public sector and policy implications for developing countries

$\begin{array}{r}\text { PROBLEMS } \\ \text { OF MANAGEMENT } \\ \text { IN THE 21 } 1^{\text {st }} \text { CENTURY } \\ \text { Vol. 12, No. 1, 2017 } \\ \hline 12\end{array}$

\section{Ethical Consideration of the Research}

Any research involving human and animal subjects requires ethical clearance from the relevant institution. The present research, as it involved human subjects, was approved by the Committee for Ethics in Human research at the University of Canberra, Australia. It followed the general conditions determined by the university policy and the National Statement on Ethical Conduct in research involving Humans (National Health and Medical Research Council, 1999). In this research, to understand the purpose of the research, each of the participants was provided with a Participant Information Form which included the title of the research, details of the researchers and the supervisors, project aim and benefits, general outline of the project, participant involvement, confidentiality, anonymity, data storage system, ethics committee clearance and queries and concerns about the research project. Each participant was also provided an Informed Consent Form. Before conducting the formal interview, the participant was required to sign the Consent Form stating that the participant understood the information about the research. Both the Participant Information Form and the Informed Consent Form were approved by the Committee for Ethics in Human Research, University of Canberra. Participation in this research was voluntary.

\section{Results of Research}

It has been observed that the researched organization has implemented a wide range of reforms linked to new public management. The main objective of these reforms is to promote a culture of performance in the public sector. It helped to achieve cost efficiency, budget accountability and to adopt a customer focus in service delivery. At the same time the selected public sector organization implemented a range of measurement strategies to obtain a better result. These are very important for them, as one of the senior executives commented:

If the public are not happy with our service they can go to a politician and take the issue up and there is also the media scrutiny because of the focus of the political process. So that there is a form of scrutiny and I think we are much more exposed than the corporate world.

Evidence from the field supported that the researched organization uses financial and non-financial performance measures in their organization to develop individual and overall business improvement at the operational and strategic level.

\section{Financial Performance Measures in the Selected Public Sector Organization}

Financial performance evaluation and reporting have long been used to help evaluate the relative success of business activities (Alam, 2006). To obtain better results the conventional language of accounting (performance standards) became part of the frame of meaning used to make sense of activities at the researched organization. Though it is in the initial stage but the department uses the performance measurement system as one of a number of tools that direct and support organizational change and performance. As one senior executive of the organization put it:

We have a reporting system to the government around key financial performance indicators. I think there are some challenges and some work to do in getting around and making it right. We have the beginning but some of these things particularly in the service organization are difficult to quantify. But increasingly as we are connected into the debate nationally with other jurisdictions we are getting more unified views about the things. 
Anup CHOWDHURY, Nikhil Chandra SHIL. Performance measurement systems in the context of new public management: Evidence from Australian public sector and policy implications for developing countries

The opinion expressed by another senior executive of the department confirmed this

\author{
PROBLEMS \\ OF MANAGEMENT \\ IN THE $21^{\text {st }}$ CENTURY \\ Vol. 12, No. 1, 2017
}

view:

In our department every single branch has financial performance indicators; they are published in the budget papers annually. There are targets and actual results and also there is variances process similar to the private sector. We have really adopted those things as an indicator. People in the department then have twelve months to try and reach the target.

It is important to mention here that in the department these performance indicators are similar to those which are used in the private sector. Interviewee elaborated this view further:

Rather than sales targets as you get in the private sector or margin targets or a number of units of manufacture etc. ours are similar in a way which are hours of service provided or the number of clients seen. We are not selling something so you don't ever increase sales targets. We don't get that. But by the same token there's an expectation that you have a service delivery target that always increases. Companies always want to see the curve in the graph going up. If it's going down something is in trouble. It is very similar in the public sector these days. You never used to measure those things and there was never any accountability around it in the past. In our estimate process people's focus is on it. It's all about what "why are you spending less money on this area? Why haven't you achieved this target? Why is this target flat lining rather than going up"?

Evidence from the field and departmental documents supported that the performance measurement process of the researched organization is the product of business and corporate strategies. These strategies also outline operational priorities. The department has four output classes. The department exhibits their financial performance in these four output classifications. The department's financial performance measurement process is undertaken by monitoring these outputs and matching performance targets with budgeted and actual expenditures.

The researched department's financial measurement system is published in the budget papers every year and these are public documents for anyone to look at. The department shows their expected outcome and all of their different outputs there. At the end of the financial year, the department publishes its annual report which is the actual result against the department's budget. The department then has annual report reviews and faces all sorts of questions in public view. The department has to answer to a number of external constituencies. So, there is heavy scrutiny in terms of their financial measurement process.

\title{
Non-Financial Performance Measures in the Selected Public Sector Organization
}

Modell (2004) argued that public sector organisations have come under increasing criticism for placing too much attention on financial control and suffering from excessive proliferation of performance indicators. Modell concluded that non-financial performance management indicators and goal-directed multidimensional models may gradually replace the myth that public service provision may be improved by heavy reliance on financial control. The selected department is not an exception in this regard. The department's major priorities are: delivering the highest possible level of client services, incorporating community, business and government as partners. It was evident from this research that the department has developed non-financial performance measures. These measures are related to accountability indicators for every output classification. These indicators show that the department uses targets, estimated outcomes and the subsequent year's targets. Non- financial performance measurement system of the department was described by one of the junior staffs of the department as follows: 
Anup CHOWDHURY, Nikhil Chandra SHIL. Performance measurement systems in the context of new public management: Evidence from Australian public sector and policy implications for developing countries

$\begin{array}{r}\text { OF MANAGEMENT } \\ \text { N THE 21 } 1^{\text {st }} \text { CENTURY } \\ \text { Vol. 12, No. 1, 2017 } \\ \hline 14\end{array}$

PROBLEMS

We have a number of financial indicators that link to an output based budget. There are four outputs to the department that are further broken up to output classes and they all have strategic indicators placed against them which are mostly non- financial.

The department has developed eight strategic indicators to measure their performance which are subjective. These indicators are mostly non-financial. These are the number of service users by service type accessed, number of clients accessing services, number of families accessing services, re-substantiation rates, community services grants, number of groups participating in the annual national multicultural festival, recidivism rates for young people, and children. One of the senior executives of the department commented:

If we meet our targets or achieve our targets it's a measure of our performance. For example, we have set ourselves some very keen standards and we have changed the eligibility criterion of public housing to target people with very low incomes and complex needs so we are addressing the needs of people who have the greatest need. We reduced our waiting list and that is a good thing. We set ourselves a target that people who fit the highest needs group then could be housed up to $85 \%$ in three months. We have exceeded that target. Before we changed our rules people in the highest needs group were waiting 12 months for housing and now $85 \%$ of them or less are waiting for three months.

One of the mid-level executives of the department commented in a different way:

Though we are using financial and non-financial performance measures we are struggling a lot. As you know government performance is difficult to measure because the outcome depends on too many factors and the involvement between the effort and the effect are very long. We are sometimes confused also.

Therefore, in the performance measurement system, there might be some side effects also. This control mechanism may lead to a lack of goal congruence when employees try to achieve the performance targets in a way that is not desirable for the organization.

The department evaluates their non-financial performance also through client satisfaction survey. This is done independently and which is not done in the private sector. There are different ways that the department conducts surveys and the different indicators used to determine how or what the department are doing. This was evidenced in comments by one of the mid-level executives of the Department:

Each of our agreements within the community sector has a performance measure and there is a quality assurance system in there. There are also performance issues in meeting the outputs we have purchased. There definitely needs a lot more work on measuring the qualitative attributes. We do those processes to ensure that there is accountability through our agreements. We do satisfaction surveys on our client. So if the clients are satisfied we can readily say our performance is good. These measures are reported annually in the annual report and we are accountable to government as well.

One of the senior executives in the department expressed a similar view:

Our own measurements are something that we do focus on to increase our satisfaction. Every second year there is an external measurement of public housing satisfaction against a number of indicators. This is a survey of our tenant service which is taken independently using the methodology and is comparable to costs within the States and the Territory so that we can benchmark our tenant satisfaction against a whole range of measures against our colleagues in other states and territories. Our own survey does not stop here. We use the same methodology in terms of a key measurement of the satisfaction of clients within the constituency and we can benchmark either improvements or decrease performance against certain year to year services. 
These performance measurement actions reshaped department's signification structure (Giddens, 1979; 1984). These performance standards became part of the frame of meaning used to make sense of activities and which previously had been understood only in traditional service provider terms.

\section{Discussion}

In an organization, the structure of signification (Giddens, 1976, 1979, 1984) refers to how purpose and meanings are attributed to everyday activities. In the public sector there has been a long tradition that public organizations provide utilities and services to the community and have been seen as the fabric of the society. These organizations are funded by government grants raised from taxation and provide supply services and utilities which is part of the infrastructure of the society. No attempt had been taken to measure efficiency or effectiveness of government spending for a long time. This was the old signification structure of the traditional public organizations. Such structure of signification did not go unchallenged. The movement away from this situation has emerged and the emphasis is given on efficiency, economy and effectiveness and streamlining performance measurement in the public sector. The new notion, 'value for money', has emerged in the public sector which established formal rational management, clear goals, corporate plans, internal and external accounting system and clear responsibility lines for output measurement. The change to structure of meaning and signification was seen in the researched government department too. In the department a competing interpretive scheme of signification became apparent. New public management brought a challenge to the signification structure of the department and required to implement new interpretive schemes. To meet the demands of the NPM initiatives, the researched government department implemented performance measurement systems as interpretive schemes in their organization. This new interpretive scheme is the financial and nonfinancial performance measures which mediate between the signification structure and social interaction in the form of communication between managers and employees. The elements of the new interpretive schemes are reporting systems to the government, financial performance indicators, budget papers, annual reports review in front of public etc.

According to Giddens $(1979 ; 1984)$, the domination dimension of social life includes facilities through which actors draw upon the structure in the exercise of power. In a broad sense, power is considered as the ability to get things done and in a narrower sense; it simply implies domination (Busco, 2009). Resources, or facilities both allocative and authoritative, are the media through which power is exercised. Allocative resources arise from command over objects, goods and other material phenomena and authoritative resources result from the domination of some actors over others. Craib (1992) pointed out that material resources are a necessary condition for the exercise of power and authoritative resources are increasingly important as they are needed to control and co-ordinate activities in modern complex organizations. Macintosh and Scapens (1990) argued that both types of resources facilitate the transformative capacity of human action (power in the broad sense), while at the same time providing the medium for domination (power in the narrow sense). In this sense, performance measurement systems are conceptualized as socially constructed resources which can be drawn upon in the exercise of power in both senses.

In the department, performance measures are facilities that management at all levels uses to coordinate and control other participants. Here, non-financial performance measures are used as domination modalities. As power is the ability to get things done, management of the department uses non-financial measures to provide facilities in the form of client accessing service, re-substantiation rates, community service grants etc. Management is able to use their power to legitimate the employment of the organization's allocative resources in the interests of employees. These are the material phenomena, which the department provides to its members to exercise power. 
Anup CHOWDHURY, Nikhil Chandra SHIL. Performance measurement systems in the context of new public management: Evidence from Australian public sector and policy implications for developing countries

PROBLEMS

OF MANAGEMENT

IN THE $21^{\text {st }}$ CENTURY

Vol. 12, No. 1, 2017

Traditionally public organizations were involved in providing services to the people. The morality was that all people should have access to these services. Resources should be available to all according to need (Lawrence \& Doolin, 1997). In the public sector, it was also observed that if funds are not enough, then it is a problem for the funding authority, not for the providing agencies. In that case spending to the limit or over the limit was common practice. Therefore, in a financial sense the structure of legitimation allowed spending without accountability (Lawrence \& Doolin, 1997). But, by introducing NPM in the public sector, the scenario has changed. In the department, a new legitimation structure appeared in response to the new public management initiatives to challenge this traditional view. New organizational purposes required new systems of financial accountability. Under this new system, managers are more accountable for their outputs. In the department, new financial accountability emerged under which it is the duty to maintain accurate accounts and records that represent a true and fair view of the financial transaction and affairs. The other legitimation structure in the department is the new moral obligation of the public service. Here, new public accountability is important and the department is accountable for acting in the public interest. This new public accountability is not providing information or answering questions. It includes setting goals, providing and reporting on results and the visible consequences for getting things right or wrong. The department developed new morale or performance measures which are designed to help employees make informed choices about their behavior and to communicate department's core values of honesty, respect, confidentiality, professionalism and fairness. Employees apply these new values in performing their duties. These ideals are the new ethos derived from the public sector reforms by introducing New Public management ideals.

In the researched department, it is evident that management control systems are modalities of structuration in the three dimensions of signification, domination and legitimation. It shows how managers and employees make sense of organizational events and activities. In the department, performance measurement systems are both the medium and the outcome of interaction because in the organizational setting these control devices are constituted by human agency and at the same time are also guided by them. Therefore, duality of structure is evident in the department. It means structure and agency exists in a recursive relationship.

\section{Limitations of the Research}

The research was limited to the practice of performance measurement systems in a government department in Australia. The characteristics of the government sector generally differ from the private sector in terms of profit motives, proprietary versus political interests, users and resource allocation process, external scrutiny, employee characteristics and legal constraints etc. However, it is evident from the research that the NPM initiatives forced the researched organization to promote private-sector models of organization structure, management systems, accounting policies and accountability relationships.

Another limitation of the present research is that it is a single case study and the findings cannot be generalized to a wider population. However, in this research the single case study was the preferred method because the research was an attempt to understand in-depth how performance measurement systems were implicated in their wider organizational setting. It was not the objective to express the general overview of other organization. As Stake (1995) argued, case study research is not a sampling research. He pointed out that a case study is expected to catch the complexity of a single case. Yin (2009) mentioned that choice of designing single or multiple sites depends on the research question. In the present research, the researcher was interested to use single site because it fits with the research questions. For another reason, multiple sites were not the option taken as multiple case study approach is used for a crosssite comparison (Eckstein, 1975; George, 1979; Hussain \& Hoque, 2002) which was not the objective of this research. 


\section{Conclusions and Policy Implications for Developing Countries}

The empirical evidence presented in this research supports the fact that the selected Australian government department has implemented performance measurement systems within the organization to illustrate the department's commitment to efficiency and accountability. As a government department, the researched organization is committed in achieving economy, efficiency, and effectiveness, the major objectives of the public sector reform agenda, by introducing new public management ideals. It also helped probity and accountability for spending tax payer's money. The research findings offer a great opportunity to public sector organizations in developing countries to initiate reforms under new public management regime to run public privately.

It appears that the researched organization has adopted these private sector performance measurement systems and has been transformed into a new kind of organization. The researched organization is providing services to the community and they are accountable to the community. As a public organization the researched organization does not have any outside equity interest and have no shareholders. They do not pay dividends through a process of corporate deliverance. However, they pay social dividends in the manner of services and if they are not experiencing that in a positive and free flowing way they make the effort to adjust their situation strongly just the same as a shareholding body.

The findings reported in this research will be of value to the developing countries as this control device is very important for today's government organizations as there is a significant reduction in government spending and at the same time increased demand exists for quality services within the community. The department's experience can be a lesson for developing countries, where we can consider the department's experience in implementing the new management control tools. Public sector organizations in the developing countries can publish their financial measures in the budget papers, where they can show their expected outcome and all the different outputs. At the end of the year the public sector organizations can publish their annual report and can organize annual report reviews, where they will explain all sorts of questions in public view. Like Australian public sector, public sector organizations in the developing countries can conduct independent client satisfaction surveys, which will definitely improve their service and at the same time will ensure efficiency and effectiveness.

\section{References}

Alam, M. (2006). Stakeholder theory. In Z. Hoque, (Ed.) Methodological issues in accounting research: Theories and methods (pp. 207-222). UK: Spiramus Press Ltd.

Barrett, P. (2004). Financial management in the public sector - how accrual accounting and budgeting enhances governance and accountability. Address to the challenge of change: Driving governance and accountability. CPA Forum 2004, Australian National Audit Office.

Boland, T., Fowler, A. (2000). A systems perspective of performance management in public sector organisations. The International Journal of Public Sector Management, 13 (5), 417-446.

Brignall, S., Modell, S. (2000). An institutional perspective on performance measurement and management in the new public sector. Management Accounting Research, 11 (3), 281-306.

Buckmaster, N. (1999). Associations between outcome measurement, accountability and learning for non-profit organisations. The International Journal of Public Sector Management, 12 (2), 186197.

Busco, C. (2009). Giddens' structuration theory and its implications for management accounting research. Journal of Management and Governance, 13 (3), 249-260.

Chua, W. F. (1988). Interpretive sociology and management accounting research - A critical review. Accounting, Auditing and Accountability Journal, 1 (2), 59- 79.

Coventry, H., Nutley, S. (2001). Change management. In C. Aulich, J. Halligan and S. Nutley (Eds.), Australian handbook of public sector management (pp.163-173). NSW: Allen \& Unwin.

Craib, I. (1992). Anthony Giddens. Routledge, London. 
Anup CHOWDHURY, Nikhil Chandra SHIL. Performance measurement systems in the context of new public management: Evidence from Australian public sector and policy implications for developing countries

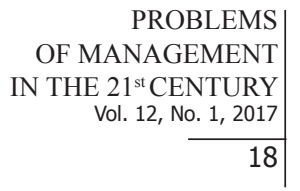

Cresswell, J. W. (2007). Qualitative inquiry \& research design: Choosing among five approaches. CL: Sage Publications.

Diefenbach, T. (2009). New public management in public sector organizations: The dark sides of managerialistic enlightenment. Public Administration, 87 (4), 892-909.

Eckstein, H. (1975). Case study and theory in political science. In F. I. Greenstein and N. W. Polsby, (Eds.), Strategies of inquiry (pp. 79-137). Addison-Wesley.

Evans, P., Bellamy, S. (1995). Performance evaluation in the Australian public sector - The role of management and cost accounting control systems. International Journal of Public Sector Management, 8 (6), 30-38.

Gaffikin, M. (2008). Accounting theory: Research, regulation and accounting practice. NSW: Pearson Education.

Geertz, C. (1973). The interpretation of cultures. NY: Basic Books.

George, A. L. (1979). Case studies and theory development: The method of structured, focused comparison. In P. G. Lauren (Ed.), Diplomacy: New approaches in history, theory, and policy (43-68). NY: Free Press.

Giddens, A. (1976). New rules of sociological method: A positive critique of interpretative sociologies. NY: Basic Books, Inc.

Giddens, A. (1979). Central problems in social theory. London: The Macmillan Press Ltd.

Giddens, A. (1984). The constitution of society: Outline of the theory of structuration. Berkeley: University of California Press.

Glaser, B. G., Strauss, A. L. (1968). The discovery of Grounded Theory: Strategies for qualitative research. Weidenfeld \& Nicolson.

Guba, E. G., Lincoln, Y. S. (1981). Effective evaluation. SF: Jossey-Bass.

Halligan, J. (2009, November). Performance and public management in Australia and New Zealand. Paper presented at the International Conference of the Institute of Public Administration, Riyadh, Kingdom of Saudi Arabia.

Heinrich, C. J. (2002). Outcomes-based performance management in the public sector: Implications for government accountability and effectiveness. Public Administration Review, 62 (6), 712-725.

Hesse-Biber, S. N., Leavy, P. (2006). The practice of qualitative research. London: Sage Publications.

Hoque, Z. (2008). Measuring and reporting public sector outputs/outcomes: Exploratory evidence from Australia. International Journal of Public Sector Management, 21 (5), 468-493.

Hughes, O. (1995). The new public sector management: A focus on performance. In J. Guthrie, (Ed.), Making the Australian public sector count in the 1990s (pp. 140-143), NSW: IIR Conferences Pty Ltd.

Hussain, M. M., Hoque, Z. (2002). Understanding non-financial performance measurement practices in Japanese banks: A new institutional sociology perspective. Accounting, Auditing and Accountability Journal, 15 (2), 162-183.

Irvine, H., Gaffikin, M. (2006). Methodological insights: Getting in, getting on and getting out: Reflections on a qualitative research project. Accounting, Auditing and Accountability Journal, 19 (1), 115 145.

Jansen, E. P. (2004). Performance measurement in governmental organizations: A contingent approach to measurement and management control. Managerial Finance, 30 (8), 54-68.

Kloot, L., Martin, J. (2000). Strategic performance management: A balanced approach to performance management issues in local government. Management Accounting Research, 11 (2), 231-251.

Lawrence, S., Doolin, B. (1997). Introducing system contradiction to effect change in the public sector: A New Zealand case study. International Journal of Public Sector Management, 10 (7), 490-504.

Llewelyn, S. (2003). Methodological issues- What counts as "theory" in qualitative management and accounting research? Introducing five levels of theorizing. Accounting, Auditing \& Accountability Journal, 16 (4), 662-708.

Macintosh, N. B., Scapens, R. W. (1990). Structuration theory in management accounting. Accounting, Organizations and Society, 15 (5), 455-477.

Maor, M. (1999). The paradox of managerialism. Public Administration Review, 59 (1), 5-18.

Mason, J. (2002). Qualitative researching. London: Sage Publications Ltd.

McAdam, R., Hazlett, S., Casey, C. (2005). Performance management in the UK public sector: Addressing multiple stakeholder complexity. International Journal of Public Sector Management, 18 (3), 256-273. 
Anup CHOWDHURY, Nikhil Chandra SHIL. Performance measurement systems in the context of new public management: Evidence from Australian public sector and policy implications for developing countries

Merriam, S. B. (2009). Qualitative research: A guide to design and implementation, CL: Jossey Bass.

Miles, M. B., Huberman, A. M. (1994). Qualitative data analysis: An expanded sourcebook. London:

PROBLEMS

OF MANAGEMENT

IN THE $21^{\text {st }}$ CENTURY

Vol. 12 , No. 1, 2017 Sage Publications.

Modell, S. (2004). Performance measurement myths in the public sector: A research note. Financial Accountability \& Management, 20 (1), 39-55.

Murray, A. (2008, June). Review of operation sunlight: Overhauling budgetary transparency. Canberra.

Nagy Hesse-Biber, S., Leavy, P. (2010). The practice of qualitative research. London: Sage Publications Inc.

National Health and Medical Research Council (1999). A guide to the development, implementation and evaluation of clinical practice guidelines. Australian Government.

Osborne, D., Gaebler, T. (1992). Reinventing government: How the entrepreneurial spirit is transforming the public sector. MA: Addison-Wesley, Reading.

Parker, L. D., Guthrie, J. (1993). The Australian public sector in the 1990s: New accountability regimes in motion. Journal of International Accounting Auditing \& Taxation, 2 (1), 59-81.

Patton, M. Q. (2002). Qualitative research and evaluation methods. CL: Sage Publications, Thousand Oaks.

Ross, L. (2012). Strategic performance management in the public sector. UK: Chartered Institute of Management Accountants.

Ryan, B., Scapens, R. W., Theobald, M. (1992). Research method and methodology in finance and accounting. London: Academic Press Limited.

Sahlin-Andersson, K. (2001). National, international and transnational constructions of new public management. In T. Christensen and P. Laegreid (Eds.), New public management: The transformation of ideas and practice (pp. 43-72), Ashgate Publishing Limited, England.

Schutz, A. (1967). Collected papers. Monton.

Stake, R. E. (1995). The art of case study research. London: SAGE Publications.

Tanner, L. (2008, December). Review of operation sunlight - overhauling budgetary transparency. Canberra.

Yin, R. K. (2009). Case study research: Design and methods. CL: Sage Publications, Thousand Oaks.

Received: May 25, 2017

Accepted: July 15, 2017

\begin{tabular}{|ll|}
\hline Anup Chowdhury & $\begin{array}{l}\text { PhD, Professor, Department of Business Administration, East West } \\
\text { University, Dhaka, Bangladesh. } \\
\text { E-mail: anup@ewubd.edu }\end{array}$ \\
\hline Nikhil Chandra Shil & $\begin{array}{l}\text { PhD, FCMA, ACMA (UK), CGMA, CPFA, Associate Professor, Department } \\
\text { of Business Administration, East West University, Dhaka, Bangladesh. } \\
\text { E-mail: nikhil@ewubd.edu }\end{array}$ \\
\hline
\end{tabular}

